\title{
Incompatibilities in Turkish and European Security Cultures Diminish Turkey's Prospects for EU Membership
}

\section{Tarik Oguzlu \& Mustafa Kibaroglu}

To cite this article: Tarik Oguzlu \& Mustafa Kibaroglu (2008) Incompatibilities in Turkish and European Security Cultures Diminish Turkey's Prospects for EU Membership, Middle Eastern Studies, 44:6, 945-962, DOI: 10.1080/00263200802426229

To link to this article: https://doi.org/10.1080/00263200802426229

巴nublished online: 03 Nov 2008.

Submit your article to this journal $\square$

Џلll Article views: 457

4 Citing articles: 3 View citing articles $\square$ 


\title{
Incompatibilities in Turkish and European Security Cultures Diminish Turkey's Prospects for EU Membership
}

\author{
TARIK OGUZLU \& MUSTAFA KIBAROGLU
}

On 17 September 2007, Turkish Minister of Foreign Affairs Ali Babacan stated publicly that Turkey would proceed with the constitutional, legal, social, economic, and political reforms required by the European Union. Most of these reforms had been introduced during the previous Justice and Development Party (Adalet ve Kalkinma Partisi - AKP) government (in which Babacan was the Minister of State and the Chief Negotiator with the EU), regardless of whether new chapters were opened for furthering the accession talks that were halted with the decision of the European Commission at its December 2006 summit meeting. If Babacan's was not a populist statement that aimed to boost the morale of the pro-EU camp in Turkey, which has lost significant ground lately, it might reflect a benign neglect by the AKP government of the hard facts about the serious obstacles that stand in the way of Turkey's EU membership such as the much-pronounced opposition of the leaders of some of the leading European countries. No Turkish government can disregard the stubborn opposition of German Chancellor Merkel and French President Sarkozy to Turkey's EU membership, not to mention other like-minded politicians and community leaders in Europe who represent the prevailing negative attitudes towards Turkey in their public domains. Moreover, Turkey has become exposed to new security challenges in the Middle East following the war in Iraq led by the United States. These challenges have made it difficult to adopt the constitutive aspects of the foreign and security policies of the European Union that would make Turkey a candidate nation, thus narrowing the gap between Turkey and the EU, at least in the security domain. Added to these challenges, the EU has become more introverted in the post-9/11 era, and Islam has started to be defined as a security issue. All of these developments have, therefore, culminated in the perception of Turkey, by many Europeans, as a security burden rather then an asset.

With these factors in mind, this article will analyze the reasons why Turkey's accession to the European Union is overdue from a security perspective. The main argument is that Turkey's proximity to the Middle East, the EU's perception of Turkey as an insular country, and the nature of the country's relations with the United States have combined to produce a delay in Turkey's socialization into the EU's security culture, a precondition for EU membership. 
The fact that Turkey is situated at the intersection of different regional security complexes and that its security is closely intertwined with the developments taking place in Europe, the Middle East, the Caucasus, and Central Asia have somehow militated against the possibility of Turkey's admission to the EU from a security perspective. ${ }^{1}$ This article departs from the argument that the chances of Turkey's accession to the Union would have been much greater if the developments in Turkey's neighbourhood had eased the country's adoption of the EU's security culture.

The regional security complex theory assumes that a country is part of a specific regional security complex, if its security interests are closely intertwined with the security interests of other members of the complex. Nearly all members of the complex define their security interests and policies through common principles and prisms. $^{2}$ To Turkey's south lies a regional security complex that reflects the attributes of the so-called Hobbesian security culture. This region contains mainly weak and failed states where both traditional and non-traditional threats to security abound. The steps that these states take in order to ensure the survival of their regimes cause threats to other states as well as to their societies. To its east and north lie the rising powers of Asia, where the Westphalian understanding of international relations is still deemed valid and legitimate. These are highly sovereignty-sensitive countries, and they dislike external interference in their domestic affairs under the guise of global humanitarian concerns.

To its west, Turkey faces the European Union in which the Hobbesian culture of anarchy has long been transformed into a Kantian culture of anarchy, in the sense that the EU member states no longer define security from a state-centric perspective. The challenges to their security are postmodern in nature. Security is mainly defined as an issue of 'security governance' and 'security community building'. Involvement in other states' internal affairs is deemed legitimate, as the ongoing globalization process has helped increase the linkages between security measures in the developed and the developing world.

This article argues that although Turkey has been trying to become a member of the EU's security complex (where the rules of interstate relations are being increasingly defined on the basis of postmodern understandings of nationhood, security, and governance ${ }^{3}$ ), a series of developments have delayed this process. Turkey's proximity to the 'Greater Middle East', where the rules of international relations are still predicated on the nature of the Westphalian system, is foremost.

On the one hand is the continuation of the EU's perception of Turkey as an insular country. Turkey serves as a buffer zone between Europe and the Middle East in such a way that the country shields EU security interests from the dangers that might potentially emanate from the Middle East. The EU's perception of Turkey as an insular country perpetuates Turkey's security predicament, in the sense that Turkey does not feel itself to be part of the EU security complex. ${ }^{4}$ The EU's ambiguous approach towards Turkey's membership is not conducive to an understanding and adoption of the EU's internal security.

On the other hand is the growing Middle Westernization of Turkey's foreign and security policy. Recent developments in the Middle East, particularly right after the US-led war in Iraq, revealed that Turkey's security interests are increasingly affected by what happens in this region. The more the Hobbesian security culture in the 
Middle East engulfs Turkey, the more difficult it becomes for Turkey to be a member of the EU's Kantian security complex.

Worse than this, when the EU's ambiguous approach towards Turkey combined with the conflict-producing character of the regional environment in the Middle East, a growing number of Turkish people began to view the Europeanization process as threatening Turkey's security and sovereignty. Increasing liberaldemocratization has been seen as weakening the Turkish state's ability to deal with ethnic separatism and radical Islam, as well as other non-conventional challenges to security. In an unstable regional environment, the adoption of an EU-type security understanding (meaning that the main security referents are defined as societies and individuals), runs the risk of not only weakening the Turkish state's ability to provide security, but also of leading some of its neighbours - as well as Kurdistan Workers Party (PKK)-type terrorist organizations - to conclude that the Europeanization process is something that will diminish Turkey's capability to play a leadership role in its region.

Despite the threats that seem to emanate from the Middle East, the ongoing Europeanization process could strengthen Turkey's security. However, both in some domestic circles and by some external actors Turkey's Europeanization process is seen as a tool to weaken Turkey's power in the region. The more this view is held externally, the more the security elites in the country will tend to view the Europeanization process as a liability rather than an asset.

That said, this essay argues that Turkey's delicate geopolitical location and the EU's ambiguous approach towards Turkey's membership have delayed Turkey's accession to the EU's Kantian security environment. In this environment, attempts to define security from a state-centric perspective have long been outdated. Unless the European Union ensures the survival of the Turkish state during the accession process, with the secular, homogenous, and unitary character of the Turkish Republic being respected, it is highly likely that Turkish state elites would regard the European calls for further democratization and liberalization with scepticism.

Against such a background, this essay will first discuss the main premises of the EU's security culture. Then, an attempt will be made to uncover the reasons why Turkey's efforts to adopt European security practices have, so far, remained short of yielding positive results. In this regard, the main emphasis will be on the changing dynamics of the security environment in the Middle East, following the US-led war in Iraq and the EU's growing ambiguous approach towards Turkey's accession. The conclusion will offer a brief analysis of Turkey's latest attempts to harmonize its foreign and security policy to that of the European Union.

The end of the Cold War, the growing institutionalized relations in many policy realms, and the wars in the Balkans have all played a role in the emergence of shared security practices. Furthermore, the unification of Germany, the withdrawal of Soviet troops from Eastern Europe, the possibility of an American military disengagement from Western Europe, the growing need to attach the united Germany to the EU institutions have all led EU members to devise a common foreign and security policy during the post-Cold War era. ${ }^{5}$ As a part of such efforts, the EU finally adopted a European Security Strategy in late 2003. 
However, one would find it difficult to talk about the existence of a full-fledged common EU security culture around which all members would unite. Not only the major powers of the European Union (namely, the United Kingdom, France, and Germany, who still define their foreign and security policies from a national perspective rather than a European one), but also the decades-long integration process have failed to produce common institutions that properly represent the EU's voice across the globe. In addition, the admission of Central and Eastern European countries to the EU has made the process of devising common security strategies all the more difficult.

The growing divergence among members as to how to define EU's international identity (in relation to the United States in particular), how to accommodate Islam in the EU's principles, how to deal with the growing Russian power in the East, how to approach the liberal-democratization process in the Middle East, and how to respond to Iran's growing influence in the region, indicate that the EU seems to be stopping short of adopting an adequate common foreign and security policy understanding.

Despite the failure of the EU integration process to produce an EU-wide security culture, there are some particular principles that have shaped the security practices of EU members for decades.

First, the delegation of state-level sovereignty to supra-state and sub-state actors are legitimate security practices within the EU. Sharing sovereignty within the framework of security governance is one of the pillars of the EU's security understanding. Security governance presumes a decentralized and non-hierarchical management of security affairs. Both state and non-state actors operate jointly in horizontal and vertical levels to solve security problems. ${ }^{6}$

Second, the EU's security understanding presumes the development of a security community among member states in which dependable expectations of peace would delegitimize both the threat and use of force in dealing with security issues. ${ }^{7}$ The ongoing supranational integration process and transnational interactions among the European people would help produce collectively shared norms, identities, and rules. In such an environment, pursuing traditional balance-of-power security practices would seem illegitimate and counterproductive. The continuation of the integration process is the most important security strategy, in the sense that the deeper the integration process, the less likely the old balance of power security practices would return.

Third, the enlargement process is also considered to be a security strategy. The EU would be more secure and safer, if it enlarged to the countries that are gradually embracing the EU's constitutive norms. The quicker this process, the more secure the EU would be. However, the transformation of the non-EU countries on Europe's periphery in the image of the EU's constitutive principles would be possible if the enlargement process continued on the basis of a postmodern mentality Thus, membership of aspirant states is seen as an issue of when rather than if. If the EU defined its relations with the aspirant countries on the basis of inherent differences emanating from religion, culture, ethnic background, and history, it would likely transform into a modern international actor, negating the postmodern logic behind the integration process itself. ${ }^{8}$

Fourth, the security understanding of the EU prioritizes the use of civilian and economic means in dealing with emerging security issues. Hence, relying extensively 
on military instruments to eliminate the causes of insecurity is not a legitimate option.

Fifth, given that security issues are gradually becoming globalized, solutions to globalizing security problems should be sought in multilateral regional and global platforms. Rather than pursuing a global balance of power policy to contain the rise of emerging powers in East Asia, as the US has preferred to do in the post-Cold War era, the European Union has adopted a particular approach to global governance. In this approach, goals have been defined to help project the constitutive norms of the EU integration process onto other regions. In the EU's view, global peace would come through the emergence of a global conscience that reflects the primacy of international law, rules, norms, and organizations.

Sixth, the EU's security culture emphasizes the process of de-securitization/ politicization as one security strategy. The continuation of integration would accelerate this process. ${ }^{9}$ The more integration there is, the more likely that potential issues of security would be defined as political issues. Solutions to political problems would develop through negotiation and consensus building. Politicized issues would not be seen as existential threats whose elimination would justify the threat and use of force. The process of politicization might eventually result in the enlargement of self-identity to include the other. When the other becomes part of oneself, one is able to talk about the existence of true security. The more a securitized atmosphere is established, the more legitimate would be the attempts to define security from a selfother perspective. A state's primacy over its society would be strengthened in times of crises, emergency situations, and wars.

Seventh, states are no longer the primary security referents within the EU. With the end of the Cold War era, conventional military threats to states' sovereignty and territorial integrity ceased to exist for EU members. Security issues in the European Union have broadened to include non-military issues. Threats are now increasingly defined as stemming from environmental problems, organized crime, illegal trafficking of drugs and humans, and issues of economic mismanagement. ${ }^{10}$ In addition to such threats, the EU's security strategy document mentions terrorism, proliferation of weapons of mass destruction, and failed states as other critical security threats.

Eighth, if not for the need to deal with intra-state kinds of conflicts in Europe's neighbourhood through peace operations, European public opinion would not support increasing expenditures on armament. ${ }^{11}$ The end of the Cold War has eroded the legitimization of the construction of large armies on the grounds of territorial defence and nation-building. The ideas that a state's main responsibility is to protect society against external military threats and that societal concerns can be sacrificed at the altar of state security are contested today. Security practices within the EU have increasingly been based on the idea that states' legitimacy would, from now on, be based on their capability of governing effectively and responsibly. So long as states contribute to individual and societal security, meaning the preservation of ideational claims of human beings and communities, they would be considered legitimate. ${ }^{12}$

These principles and the EU's security strategy document notwithstanding, two developments appear to have recently contributed to the re-emergence of modern/ realpolitik security practices in the EU. One is the latest round of the enlargement process, whereas the other is the growing unease with the US national security 
strategy in the Middle East in the post-9/11 era. These two factors have, for instance, curtailed the EU's willingness to adopt an inclusive postmodern approach towards Turkey. However, rather than this being the case, these developments have helped perpetuate Turkey's image as an insular/buffer-zone country in EU circles. ${ }^{13}$

The EU has entered a period of reflection, following the latest round of the enlargement process in 2004 and the rejection of the European Constitution in the national referenda held in France and the Netherlands in 2005. One can now observe increasing public disenchantment with the continuation of the widening and deepening processes of the EU. Public opinion has begun to oppose the integration project, mainly because it still reflects an elite-driven nature, and the accession of new members has contributed to the rise of ideational and societal insecurity. ${ }^{14}$ In such an environment, the majority of Europeans have begun to view Turkey as a potential 'other' of the EU, rather than as a candidate country destined to join the EU. The perception that the membership of Turkey, 'too different, too poor, and too big a country', would be likely to put a brake on the integration process has increasingly transformed into a reality. Not only the Christian Democrats in Germany but also the political right in France are starting to see Turkey as a burden/ liability for the EU, rather than an asset. It is worth mentioning, in this regard, that the debate in France between then presidential candidates Sarkozy and Royal well demonstrated the rise of the 'logic of identity' over the 'logic of interests' and the 'logic of cosmopolitan rights' as far as Turkey's accession to the Union is concerned. A recent study also makes it clear that those who object to Turkey's accession to the EU through the prism of 'logic of identity' are gaining ground over those who argue for Turkey's accession through the 'logic of interests' and of 'cosmopolitan rights'.

Theoretically speaking, those who have traditionally argued against Turkey's membership tried to justify their view by referring to the unbridgeable inherent differences between the parties in terms of cultural, historical, religious, and geographical considerations. They think that Turkey simply does not satisfy European criteria in such realms. Generally they oppose Turkey's membership due to the country's Islamic background and oriental culture. In their view, Turkey should not be admitted to membership, because the EU is overwhelmingly a Christian entity. There are some inherent differences between the two sides that make it nearly impossible for the EU to see Turkey as part of its collective identity.

Another version of the ideational logic holds that the secular state-society practices in EU countries have succeeded because the EU's Christian past has paved the way for it. A Christian past and secularism are constitutive of each other. Because Turkey does not have a history of Christianity, they reason it can never become a secular country. Islam and secularism are essentially in conflict with each other. Neither secularism nor democracy is compatible with Islam. These circles argue that in order to become secular, one must come from Europe's JudeoChristian past. This is an essentialist way of explaining how secularism took root in Europe but not in the Islamic world. ${ }^{16}$

The parties that have traditionally adopted more sympathetic views about Turkey's accession to the EU have tried to justify their opinions either on the grounds of economic and security benefits for the EU or on the appropriateness of the idea that the EU should let Turkey in if it adopts the EU's cosmopolitan values of democracy, human rights, and liberalism. 
Those who try to argue for Turkey's membership from the logic of interests voice the following points. Turkey provides a huge market for European industry; it is a gateway to the emerging markets of the Central Asian and Middle Eastern states; Turkey's transit route between Europe and Central Asia can help the EU decrease its over-dependence on Russian gas and oil; Turkey has a growing Europeanizing young population that could potentially satisfy the labour demands of the EU's dwindling economies; when the time comes for Turkey's eventual accession to the EU, its per capita income will have reached at least $\$ 15,000$; Turkey has been a member of NATO for the last five decades and has a culture of security cooperation with the European members of the alliance against common external threats; Turkey has a well-trained army that can help the EU meet the emerging demands in the realms of peace operations across the globe; Turkey can protect the EU's Kantian security environment against the dangers that might potentially emanate from the Hobbesian security environment in the greater Middle Eastern region; with Turkey inside, the hard and soft power of the EU will increase, for Turkey's membership will certainly increase the EU's capabilities and its power of attraction across the globe, particularly in the Islamic world. ${ }^{17}$

On the other hand, those who argue against Turkey's membership through the logic of interests refer to the following points. Turkey is simply too big and too poor; the EU would not be able to digest Turkey's membership painlessly; Turkey's economy is not developed, and its membership would create additional strains on the EU's Common Agricultural Policies; the EU would need to finance Turkey's agricultural economy; with Turkey in, Iran, Syria and Iraq would become neighbours of the European Union; the EU does not need Turkey's membership in order to see that Turkey cooperates with the EU in the realm of security, for Turkey's NATO membership already provides the mechanisms of such cooperation; Turkey's membership will certainly slow down the EU's integration process, which is considered one of its vital security strategies; Turkey's membership might enable the United States to help weaken the EU's potential power, for Turkey would likely prove to be a staunch member of the Atlanticists' caucus inside the EU. ${ }^{18}$

Those who argue for Turkey's membership through logic of cosmopolitanism reasoning simply claim that Turkey should be allowed into the EU, for the EU's integration process is not regulated by Christianity, geography, or culture. The EU is not a geographical project but a political one. The more Turkey ascribes to liberaldemocratic norms of the EU family of nations, the more legitimate will be its inclusion in the EU. The EU's secularism has nothing to do with Christianity, and the EU is a secular, postmodern, and multicultural entity taking its legitimacy from the principle of 'unity in diversity'. Turkey's membership would reinforce the EU's multicultural identity. To this reasoning, there is no constitutive relationship between Christianity and secular state practices in EU countries. Secularism is an acquired characteristic. Therefore, if Turkey proved that it is a secular state, in which the rules of political life do not take their legitimacy from religion, the prospects for Turkey's accession to the Union would certainly increase.

That said, the debate between Sarkozy and Royal was quite representative of the clashes among these alternative logics. For example, Sarkozy believes that there are some inherent differences between Europe and Turkey based on religion, culture, and geography. It is difficult, if not impossible, to get rid of such differences, because 
they have been ingrained in the mindset of the European people. For example, Sarkozy believes that 'it would be a daunting task to tell French children why Turkey was admitted to the European Union'. In this view, Turkey stands at the opposite end of what the contemporary European civilization stands for. Rather than engaging Turkey in the accession process, Sarkozy suggests that Turkey needs to be included in a new Mediterranean initiative, whose goal would be to help replicate the success story of the EU integration process among the Mediterranean countries. $^{19}$

Another factor that appears to have affected the EU's growing scepticism towards Turkey's accession in the post-9/11 era pertains to the EU's dissatisfaction with the emerging security environment in the Middle East, following the US-led war in Iraq. Rather than adopting a policy to help contribute to the transformation of the region along liberal-democratic norms, the EU seems to have avoided the growing turmoil in the region. The EU has not shared the American rationale behind the war on terror or the American explanation for why the Iraqi regime should have been dethroned through a war. Europeans simply concurred that the American responses to the 11 September 2001 attacks have increased rather than decreased threats to European security. ${ }^{20}$ Worth mentioning in this regard are the terrorist attacks in Spain and the United Kingdom, the growing European intolerance against newcomers, the resurgence of xenophobia and nationalist feelings, and the erosion of multiculturalism in the Netherlands and the United Kingdom.

The possibility of Turkey's membership in the EU has significantly decreased, as a growing number of Europeans have begun to define Islam as a security issue in the post-Iraq war era. The influence of the European circles who traditionally argue that Turkey's membership would contribute to the Europeanization of Islam has decreased relative to those who argue that the Islamization of Europe would become a serious possibility once Turkey has joined the Union. ${ }^{21}$

Furthermore, the idea that the EU should now focus on its internal problems, rather than enlarge itself or play a global security role in the Middle East, has gradually become more legitimate in the post-9/11 era. Some Europeans tend to argue that the idea of 'fortress Europe' would be the best way to deal with growing insecurity. In such an environment, the possibility of the EU offering Turkey the prospect of a credible membership remains low.

The EU decision in December 2006 to partially freeze accession negotiations with Turkey demonstrates well that the number of Turkey-sceptic circles within the EU has increased. The danger here is that if Turkey finds itself estranged from the European Union, the portrayal of the EU as a rival and enemy of Turkey could become a reality. And, in the absence of the Europeanization process, Turkey's secular identity might erode. Given that secularization and westernization/ Europeanization processes have gone hand in hand, any break in the latter might negatively impact on the former. This will certainly be considered an anathema for Turkey's Kemalist security identity. ${ }^{22}$

In addition to the EU's growing scepticism towards Turkey's accession, Turkey's efforts to follow the former's security practices have also been negatively affected by the dynamics of its relationship with the United States. Such effects are twofold. The first stems from the lure of American security culture to Turkish security elites. The similarities between the two have led Turkish elites in the past to seek Turkey's future in closer strategic relations with the United States. The second pertains to the 
growing insecurity and instability in the Middle East caused by the American security behaviour in the post-9/11 era.

The US-led war in Iraq, the US approach towards Iran and Syria, and the democratization question in the Middle East have helped to produce an insecure regional environment that has, in turn, curtailed Turkey's ability to undertake the liberal-democratization process at home, a precondition for membership in the EU. The post-9/11 developments in Turkey's neighbouring regions have amplified traditional and non-traditional threats to Turkey's security. In an atmosphere of increasing security, Turkey's efforts to adopt a society-based security understanding fall short of meeting EU standards. In other words, the adoption of the EU's security culture by Turkey has also been hampered by the US-led developments in the Middle East in the post-9/11 era.

The US war in Iraq has emboldened the Iraqi Kurds in their efforts to seek independence, a nightmare for Turkey. Increasing Kurdish nationalism in Iraq has derailed Turkey's efforts to solve its own 'Kurdish problem' through liberal democratic means. Besides, the PKK attacks have surged. The PKK has continued to use northern Iraq as a sanctuary, and whenever Turkey has wanted to pursue PKK terrorists in northern Iraq, Americans have declined to cooperate. Despite the fact that both countries have recently established a new institutional mechanism to coordinate their efforts against the PKK (the so-called 'institution of representatives') and that they have initialled a new strategy document in which they pledged to assist each other against the PKK, no concrete results have been achieved from such developments. ${ }^{23}$

For Ankara, the eradication of terrorism by the PKK would not be possible unless the Kurdish leaders in northern Iraq viewed the PKK through Turkey's eyes. The idea that if Turkey really wants to get rid of the PKK problem it should first improve the domestic situation of the Kurds in Turkey does not seem convincing enough, for Turkey makes a clear distinction between the Kurdish question and the PKK's terrorism. Neither the majority of public opinion nor the Kemalist security establishment believes that Turkey has a specific Kurdish problem, in the sense that Turkey's Kurdish-originated citizens have been negatively discriminated against due to their ethnic backgrounds. The reality is that all Turkish citizens, irrespective of their ethnic, linguistic, or religious backgrounds, appear to suffer from some structural problems in the realms of economic development and democratization. However, Turkey has certainly had a terrorism problem since the PKK took up arms against the Turkish state with a view to contributing to the emergence of an independent Kurdistan in the southeastern part of Turkey. A poll conducted by the prestigious Milliyet newspaper has revealed that the majority of Turks think that the number one reason for the PKK's resilience is the support that the PKK receives from external actors. ${ }^{24}$ Without the strategic depth that northern Iraq seems to offer the PKK, Turkey could easily eliminate it. The danger here is that the continuation of PKK terrorism appears to keep Turkey's democratization process hostage, for fighting the PKK would likely require extra security measures that might contradict the gist of the liberalization process.

Another risk is that if Iraq's future were to reflect ethnic differences, the ethnicization process of Turkey's Kurdish question would be likely to gain momentum. Whether or not Turkey's Kurds are increasingly attracted to the emerging political authority in northern Iraq is a serious question that Turkey's security policy makers must take account of, while they define Turkey's national security interests in the years to come. Turkey is a typical unitary state in which 
ethnically diverse groups are not recognized as minority groups endowed with positive discrimination. Any Kurdish aspiration of gaining collective rights on the basis of ethnic differences is an anathema to Turkey's foundational ideology.

What worries Ankara is the fact that some of the key figures of the Democratic Society Party (DTP) in Turkey, such as Leyla Zana, have referred to Massoud Barzani, Jalal Talabani, as well as Abdullah Ocalan as the leaders of the Kurdish independence movement in the region. The Turkish security establishment has been highly suspicious of the rising influence of Barzani, in particular, on the Kurds of Turkey.

Another factor that decreases the legitimacy of Europeanization as a securityproducing process is the growing perception in Turkey that not only the PKK but also Iraqi Kurds view Turkey's Europeanization process from an instrumental perspective, in the sense that the more Turkey is engaged in this process, the more leverage they may have over the Turkish state. ${ }^{25}$ The fear here is that the Europeanization process may result in Turkey's dismemberment along ethnic lines. It is worth mentioning in this regard that when EU authorities have warned the PKK and its sympathizers in Turkey against the dangers of escalating terrorism and of pursuing an ethnic-separatist agenda, they have felt uneasy and disillusioned. Since the middle of 2004 when the PKK reactivated its terror campaign against the Turkish State, various EU officials, including the commissioner in charge of the enlargement process Oli Rehn, have counselled the DTP leadership not to support the escalation of terrorism but to countenance the ongoing EU accession process as well as to drive a wedge between PKK and the DTP (Demokratik Toplum PartisiDemocratic Society Party). ${ }^{26}$ The Democratic Society Party that claims to represent the Kurdish community in Turkey does not appear to believe that the Europeanization process would completely satisfy their aspirations. Whenever the EU makes clear that Turkey's membership in the EU would guarantee Turkey's territorial integrity and secular state identity, these Kurdish groups feel frustrated. ${ }^{27}$

Given the active cooperation of the Iraqi Kurds against Saddam Hussein and their strong objection to any Turkish military incursion into the region, the US administration has not given the green light to any potential Turkish operation against the PKK in northern Iraq. Worse than this, the American warning that any military involvement in northern Iraq might halt Turkey's European vocation irritates Turkey's decision makers. Some even speculate that the main reason behind the United States' non-cooperation is Turkey's refusal to let American troops use its territory as a launching pad during the early stages of the war against Saddam. ${ }^{28}$ The commonly held fear is that the Iraqi Kurds have now replaced Turkey as the number one US ally in Iraq. The most important indication of this change of heart in Washington, DC is the Americans' increasing deference to Kurdish priorities whenever Turkey tries to pursue a muscular foreign policy vis-à-vis northern Iraq. For example, when Kurdish groups resisted the deployment of Turkish troops in the Sunni triangle in late 2003, as part of US efforts to suppress the growing insurgency, the American government simply backpedalled. ${ }^{29}$

While, on the one hand, the United States' policies in Iraq strengthen Kurdish nationalism, on the other hand, the US administration has asked Turkey to find a political solution to its own Kurdish problem. In American eyes, Turkey's further Europeanization would enable it to resolve this problem and would lead to a more cooperative, crisis-free relationship with Washington. A Turkey that still suffers 
from a Kurdish problem at home and feels estranged from the European Union would never sympathize with active US support to Iraqi Kurds.

However, from Turkey's perspective the United States is trying to keep Turkey involved in the Europeanization process, lest Ankara adopt a unilateral-nationalistic approach towards northern Iraq. Accordingly, the more Ankara is tied to the EU and sees its future there, the less able it is to obstruct the emergence of an independent Kurdish state.

Turkey's perception of Iraqi Kurds is also shaped by the inflammatory discourse of the leading figures of the Iraqi Kurdish establishment who, for example, do not hide their aspiration to form the 'Greater Kurdistan'. In addition, the proposed Iraqi Kurdish regional constitution refers to the ineffectual Sèvres Treaty of 1920 (which never entered into force) in order to justify the Kurdish claim to self-determination and political independence. Iraqi Kurdish leaders do not cooperate with Turkey against the PKK, for they see the PKK as a bargaining chip vis-à-vis Turkey. There is even speculation that once Turkey acquiesces in the consolidation of Kirkuk as a Kurdistani city, then Iraqi Kurdish leaders would start to help Turkey eliminate the PKK presence in northern Iraq. ${ }^{30}$

The US policies in the Middle East have contributed to the rise of nationalism and western scepticism in Turkey, not a conducive environment for the EU-led liberaldemocratization process. ${ }^{31}$ A wide margin of Turkish public opinion now shares a feeling of growing anti-Americanism. The rise in anti-Americanism is driven by the gap between Turkey's expectations from the United Sates and the way the United States has responded to them, particularly concerning northern Iraq. The rise in antiAmericanism is important for the reason that it also fuels Turkey's Euro-scepticism. The two are strongly interrelated. ${ }^{32}$

The prevailing view is that the current US government, under the influence of neoconservative ideology, seems to punish Turkey for its decision on the eve of the war in March 2003 for non-cooperation. The US government seems to believe that had the AKP government and the Turkish Armed Forces done their best to convince the deputies of the appropriateness of cooperation with the US then the government's motion would have been easily approved in parliament. What has endangered bilateral relations was the adoption of an ideology-driven approach, as espoused by neo-conservative circles. Turkey would like to see the old realpolitik concerns start to reshape bilateral relations.

For Turkey to join the EU's Kantian security complex, its neighbours in the Middle East would have to avoid conventional as well as non-conventional threats to Turkey's security and define their perception of Turkey, at the very least, on the basis of friendship. However, recent developments in the region have not helped to create such an atmosphere in Turkey's relations with Iran, Iraq, or Syria. The potential for conflict and rivalry among each of these countries still persists. For example, the US administration has repeatedly asked Turkey to downgrade its relations with Iran, Syria, and the Palestinian administration controlled by the Islamic Resistance Movement (Hamas). From an American perspective, Turkey would be seen as an ally if and only if it formed closer relations with Israel, disengaged itself from the Hamasled Palestinian government, and supported US goals in Iraq, Syria, and Iran. Hence, Turkey has increasingly found itself in the middle of growing American belligerency against Iraq, Syria, and Iran, on the one hand, and regional calls for rising 
anti-Americanism on the other. The nightmare scenario for Turkey would be to be forced to choose between the United States and its neighbours in the Middle East.

Given that the Middle Eastern region is now becoming the centre of global politics, due to its richness in energy resources, that rising Asian powers are now establishing economy-based cooperative relationships with countries in this region, and that anti-Americanism is on the rise across the globe, Turkey's pursuit of a proAmerican foreign and security policy might even bring more costs than benefits. If one considered the fact that Turkey's western-oriented foreign policy during the Cold War era did contribute to anti-Turkey feelings/perceptions in the region, Turkey's foreign policies would not be seen as legitimate in the future should Turkey stay the western course without an inch of change. ${ }^{33}$

Without the US dimension, Turkey could establish more cooperative relations with Iran and Syria. The Muslim as well as the Middle Eastern features of its identity could potentially help it reach out to the people in this region. For example, the AKP government, which came to power with the November 2002 general elections, wanted to capitalize on Turkey's Ottoman past and its Muslim identity in relations with countries in the Middle East. ${ }^{34}$ Besides, despite Iran's increasing geopolitical power, that country did not figure in the AKP's foreign policy agenda as an existential security threat to Turkey. Moreover, the AKP government did not share the same security perceptions of the western governments regarding Iran.

There may be an explanation for such an attitude. The two countries have not fought each other since the Treaty of Kasr'i Shirin was signed by their ancestors in 1638. The borders between the Persians (Iranians) and the Ottomans (Turks) have remained much the same ever since. Furthermore, the AKP government's security policies seemingly did not accept the argument that Iran is close to developing nuclear weapons. They hold the view that Iranian attempts to obtain nuclear energy are driven mainly by economic needs. To Ankara, the Iranian desire to acquire nuclear weapons is better explained by the desire to have international prestige and the ability to deter adversaries, rather than by the concern about changing the status quo in the region, where Iran feels itself encircled by the US presence in Afghanistan and Iraq and by Israel's nuclear power. ${ }^{35}$ In addition to this, Turkey, Syria, and Iran seem to have similar concerns regarding the rising Kurdish nationalism in Iraq, which is considered to be a threat to their respective national interests. All three governments also share the view that unconditional western support to Israel prevents the emergence of a peaceful regional order, in the sense that power disparities between these countries and Israel leads the latter to avoid any reconciliation process based on empathy and that Israel simply hopes to dictate its solution to the others.

Despite the existence of some common interests between Turkey and Iran, the developments in the post-Iraq war era might create realpolitik security practices in bilateral relations. To Turkish security policy makers, the regional balance of power might change if Iraq ceases to exist as an independent state; if Iran takes the upper hand in Iraq through its close links to the Shia groups; and if an independent Kurdistan replaces Turkey as the most critical US ally in the region. Thus far, Turkey has followed a particular foreign policy aiming at the preservation of the status quo in the region. To achieve this, Iraq's territorial integrity has been considered a necessity. ${ }^{36}$

Turkey is also concerned with the possibility that Iran or Syria would claim regional leadership. The post-Saddam era developments in Iraq appear to have bolstered Iran's relative influence compared to other actors as well as its alleged 
intentions to acquire nuclear weapons. ${ }^{37}$ For Iran not to be considered by Turkey as an existential security threat the regime in Tehran should not try to project its regime onto other countries or entertain aspirations to nuclear weapons. Nor should Iran challenge Turkey's position in Central Asia or the Caucasus by supporting Turkey's traditional 'foes' such as Armenia. The more Iran appears to be a vital threat to Turkey's security, the more difficult Turkey's Europeanization process would be. Turkey does not like to admit that it needs to increase its defence expenditure in order to counterbalance rising Iranian power in the region. The rise of a nuclear Iran would not only help decrease Turkey's relative power in the region, but would also lead many Turks to deconstruct the legacy of the decades-long support for nuclear non-proliferation policies. The question of to what extent Turkey can rely on NATO's nuclear umbrella cannot be answered with great certainty. Having nuclear aspirations would make it extremely difficult for Turkey to be admitted to the EU's Kantian security complex.

Turkey's efforts to improve its bilateral relations with Iran, sine qua non for the emergence of EU-type regional integration in the Middle East, has also been negatively impacted by the US's strong objections to Turkey's cooperation with Iran on the transportation of Iranian gas to Europe through Turkey. ${ }^{38}$ Any Turkish surrender to such American pressures might easily lead the Iranian government to view Turkey in negative terms, a development that would certainly contribute to regional insecurity.

On the other hand, despite the fact that Turkey's relations with Syria began to improve with the Adana Protocol (signed in October 1998 between the two countries, following the coercion of the former because of the documented support of the latter to the PKK), the probability that these two countries would avoid confrontation or would develop a Kantian security relationship is low. Syria has been in a strategic partnership with Iran since the Islamic revolution of 1979 and sees the rise of Shia power in the region as being to its advantage. The Syrian authorities still wish to incorporate into Syria Turkey's Hatay province, which they call Alexandretta. Official maps showing Turkey's Hatay as part of the Syrian territory hang on the walls of state buildings in Syria and are also disseminated on the websites of, among others, the Syrian Ministry of Tourism (www.syriatourism.org). The Syrian authorities also do not hide their desire for the European Union to press Turkey to accept an international mechanism that would regulate the flow and the share of the Euphrates and Tigris rivers. ${ }^{39}$

The United States' approach towards Turkey during its war against global terrorism has led the majority of Turkish secular elites to doubt whether the US wants to see Turkey as a moderate Islamic country. That, however, would contradict Turkey's secular credentials. That Turkey's significance in the eyes of Washingtonian circles appeared to have emanated from its Islamic and Middle Eastern characteristics alarmed Turkey's secular elites. They simply feared that the ongoing Europeanization/democratization process, as demanded by the United States, would result in Turkey's further Islamization. ${ }^{40}$ To the security elites, Turkey's Europeanization process is legitimate insofar as it guarantees the secular character of state-society relations in the country. Seen from this perspective, the American attempts to define Turkey as a moderate Islamic country would certainly diminish the prospects for Turkey's accession to the EU, for the latter would never acquiesce to the membership of an Islamicized Turkey. 
This essay has demonstrated that some factors have recently decreased the possibility of Turkey's accession to the EU's Kantian security regime, despite Turkey's recent efforts to accelerate the Europeanization process at home. Following the US-led war in Iraq, instability has increased in the Middle Eastern region. Turkey has increasingly been exposed to rising security challenges in the Middle East. As the region has turned out to be more Hobbesian in nature, Turkey's attempts at becoming more Kantian have somehow remained short of meeting EU standards. The more Turkey felt itself under security threats, the less it could adopt the constitutive aspects of the EU's security culture. Besides, both the EU's perception of Turkey as an insular country and its growing estrangement from the Middle Eastern region have delayed Turkey's Europeanization process in the realm of security. The more the EU has become introverted, and the more Islam has been defined as a security issue in the post-9/11 era, the less able the EU is to offer Turkey a real hope of membership. Rather than being an asset, Turkey has increasingly been seen as a security burden by many Europeans.

However, one could also mention a certain degree of optimism, until recently, especially when Turkey has taken steps in accordance with the premises of the EU's security understanding. The constitutional reforms that the Turkish parliament passed during the three-party coalition (namely the DSP (Demokratik Sol PartiDemocratic Left Party)-ANAP (Anavatan Partisi - Motherland Party)-MHP (Milliyetci Hareket Partisi - Nationalist Movement Party) government that was formed following the 1999 general elections under the premiership of Bulent Ecevit) and, more so, with the coming of the AKP to power in November 2002, have basically aimed at reducing the primacy of the military in formulating Turkey's foreign and security policies. As a result, elected politicians and civil society organizations have been more active than ever in this process. However, this has not been an easy outcome. Debate occurred inside the country about how best to define Turkey's national security interests. ${ }^{41}$ Despite the rise of nationalistic and Eurosceptic circles, Turkey's pro-EU circles (that is, the AKP government and the business community) have been influential in the policy making process.

Regarding foreign policy issues, Turkey has also gradually adopted a multilateral and regional approach in its relations with external actors. Solutions to regional problems and national security issues are increasingly sought in institutional settings. The reconciliation process with Greece and the transformation of the decades-long parameters of Turkey's policy towards Cyprus in line with the Europeanization process were striking examples in this regard. In the same vein, the Turkish government has started to act as a European country in non-European geographies, most importantly in the Middle East, by supporting the transformation of regional politics in liberal-democratic ways. Many high-level Turkish figures have frequently warned their Middle Eastern counterparts against the dangers of a continuation of the status quo regimes and their lack of democratization. ${ }^{42}$

One particular reason behind this process could be the impact of the Europeanization process on Turkey's domestic political stability, economic progress, and improved regional standing. Turkey has benefited from EU-related reforms that paved the way to growing domestic stability, which, in turn, increased the climate of confidence, a precondition for further economic investment; Turkey has attracted considerable amounts of foreign direct investment. ${ }^{43}$ 
Such an optimistic picture was pervasive, and the expectations were high, until the dramatic decision of the EU in its December 2006 summit meeting to freeze the accession talks with Turkey in eight of the 35 chapters that must be negotiated along the way to membership and to tie down the rest of the chapters, even if talks are carried out, until the resolution of the conflict emanating from Turkey's resistance to open its air and naval ports to Greek Cypriot vessels. That decision was hardly anticipated, even by the AKP government representatives who have been ardent supporters of the EU process against all odds, such as the growing anti-western attitude among their constituents.

In addition, the deterioration of relations between Turkey and the US, due to strong disagreements over how to handle the situation, especially in northern Iraq, diminished the active support of the American administration by way of lobbying in the European capitals, despite strong counter-reactions. The US, in principle, still endorses Turkey's EU membership, which is seen as a long-term policy in the right direction. However, most Americans seem to have lost their enthusiasm to advance Turkey's cause, as they have been under heavy fire from the Turkish side, where antiAmericanism is growing the fastest in the world.

Finally, in the chain of critical developments affecting Turkey's prospects for EU membership is a recurring event in Turkey, namely the intervention of the military in domestic politics in one way or another. There have been five such interventions known to the public since the 27 May 1960 coup d'état, which resulted in the execution of Prime Minister Adnan Menderes and two of his cabinet members, Foreign Minister Fatin Rustu Zorlu and Finance Minister Hasan Polatkan. A new and more democratic constitution was drafted and put into force in 1961, which, however, was replaced with one that was drafted again under the military rulers that came to power with the 12 September 1980 coup d'état. In the meantime, on 12 March 1971, the powerful generals issued a 'memorandum', which forced Prime Minister Suleyman Demirel and his cabinet to step down, paving the way to a series of short-lived caretaker governments. The year 1997 witnessed another such intervention, known as the 'postmodern coup', which was carried out in an indirect fashion by way of mobilizing large segments of the population who were sensitive about the future of the secular republican regime. The last of such interventions came 'online' on the night of 27 April 2007 with a declaration posted on the official website of the Turkish General Staff, pointing out the sensitivities of the Turkish Armed Forces and reminding the government of its duty to protect the regime and the integrity of the country. ${ }^{44}$

All three of these developments - the freezing of negotiations with the EU, deteriorating relations with the US, and the intervention of the Turkish military in domestic politics - have radically changed the mood both inside and outside the country vis-à-vis expectations of the Europeanization process. Nevertheless, one must bear in mind that all of these developments are actually the culminations of deep-rooted, multi-layered, and complex problems emanating from the very nature of Turkey's politics and the very fabric of Turkish society and culture. They have always been around, surfacing occasionally, and they are likely to stay for some time.

Even if the problem of opening air and sea ports to Greek Cypriot vessels is somehow resolved and the accession negotiation talks are resumed, another issue may become instrumental in stalling the process, mainly because of the reluctance of Europeans to give a clear prospect to Turkey for membership, especially after the 
Presidency of Nicolas Sarkozy in France, and to some extent, Angela Merkel in Germany, who are on record for their strong opposition to Turkey's full membership in the EU.

On the other hand, considering the possibility that the US may stay in Iraq and in the so-called 'Greater Middle East' for a prolonged period, confrontation between that country and Turkey is likely, at least in the political domain, due to the substantially different designs of each country regarding the future of the region. In such a confrontational framework, attributing much importance to US support for Turkey's European vocation, which may affect the outcome in favour of Turkey, would simply be misleading.

Without the EU's enthusiasm to see Turkey on board and the genuine support of the US for Turkey's EU vocation, only the internal dynamics in the country might help advance Turkey's Europeanization process. However, the intervention of the military in politics, now almost routine in ten-year periods, does not necessarily produce outcomes in that direction. The social and cultural fabric of Turkish society and the ways and means of making politics in the country, short of drawing lessons from past experiences, do not lend confidence that intervention will not happen in the future. Since the last post-modern coup in 1997, even those who had adopted a more cautious approach towards the level of maturity of the democratic culture in the country, despite all the reforms that were introduced to Turkish society and the political life in the last half-decade, have been surprised by the scale of military involvement in Turkish politics. Therefore, each bastion of Turkey's Europeanization process, namely the EU negotiations, US support in that regard, and Turkey's democratization, has its own defects and weaknesses and may not sustain the steady advance of Turkey in that direction. Hence, winning the battles (that is, the reforms in Turkey or the start of accession negotiations) does not suggest that war (which would involve full membership) can be won sooner or later. Then, the question as to what the future holds for Turkey's security predicament amid the clash of Hobbesian and Kantian security cultures becomes a valid one.

\section{Notes}

1. M. Kibaroglu, 'Security Implications of Turkey's March Toward European Union Membership', in J.S. Joseph (ed.), Turkey and the European Union: Internal Dynamics and External Challenges (Basingstoke, UK: Palgrave, 2006), pp.178-90.

2. T. Diez, 'Turkey, the European Union and Security Complexes Revisited', Mediterranean Politics, Vol.10, No.2 (2005), pp.167-80.

3. G. Sorenson, 'State Transformation and New Security Dilemmas', in E. Aydinli and J.N. Rosenau (eds.), Globalization, Security and the Nation State (New York: SUNY Press, 2005), pp.81-97.

4. B. Buzan and T. Diez. 'The European Union and Turkey', Survival, Vol.41, No.1 (1999), pp.41-57; M. Kibaroglu, 'The Generals' Discontent', The Bulletin of the Atomic Scientists, Vol.57, No.2 (2001), pp.28-30.

5. C.O. Meyer, 'Convergence towards a European Strategic Culture? A Constructivist Framework of Explaining Changing Norms', European Journal of International Relations, Vol.11, No.4 (2005), pp.523-49.

6. M. Webber, S. Croft, J. Howorth, T. Terriff and E. Krahmann, 'The Governance of European Security', Review of International Studies, Vol.30, No.1 (2004), pp.3-26; E. Krahmann, 'Conceptualizing Security Governance', Cooperation and Conflict, Vol.38, No.1 (2003), pp.5-26.

7. M.A. Smith and G. Timmins, 'The EU, NATO and the Extension of Institutional Order in Europe', World Affairs, Vol.163, No.2 (2000), pp.80-89. 
8. B. Rumelili, 'Constructing Identity and Relating to Difference: Understanding the EU's mode of Differentiation', Review of International Studies, Vol.30, No.1 (2004), pp.27-47.

9. O. Waever, 'Identity, Integration and Security', Journal of International Affairs, Vol.48, No.2 (1995), pp.389-431.

10. J. Lindley-French, 'European Defense: New Threats, New Missions and New Actors', Military Technology, Vol.26, No.6 (2002), pp.10-14.

11. A. Missiroli, 'Ploughshares into Swords? Europe for European Defense', European Foreign Affairs Review, Vol.8, No.3 (2003), pp.5-33.

12. D. Levy and N. Sznaider, 'Sovereignty Transformed: A Sociology of Human Rights', British Journal of Sociology, Vol.57, No.4 (2006), pp.657-76.

13. M.M. Gunter, 'Turkey's Floundering EU Candidacy and Its Kurdish Problem', Middle East Policy, Vol.14, No.1 (2007), pp.117-23.

14. A. Buonfina, 'Between Unity and Plurality: The Politicization and Securitization of the Discourse of Immigration in Europe', New Political Science, Vol.26, No.1 (2004), pp.23-49.

15. M.A. Ruiz-Himenez and J.L. Torreblanca, European Public Opinion and Turkey's Accession: Making Sense of Arguments for and Against (Center for European Public Studies, EPIN Working Papers, No.16, May 2007), http://shop.ceps.eu/BookDetail.php?item_id=1494.

16. E.S. Hurd, 'Negotiating Europe: The Politics of Religion and the Prospects of Turkish Accession', Review of International Studies, Vol.32, No.3 (2006), pp.401-18.

17. N. Nugent, 'The EU's Response to Turkey's Membership Application: Not Just a Weighing of Costs and Benefits', European Integration, Vol.29, No.4 (2007), pp.484-5.

18. Ibid., pp.484-7.

19. N. Sarkozy, 'Liberté, Fraternité and Modernité?' National Interest (July-August 2007), pp.14-15.

20. F.S. Berenskotter, 'Mapping the Mind Gap: A Comparison of US and European Security Strategies', Security Dialogue, Vol.36, No.1 (2005), pp.71-92.

21. L.M. McLaren, 'Explaining Opposition to Turkish Membership of the EU', European Union Politics, Vol.8, No.2 (2007), pp.256-8.

22. S. Cagaptay, Secularism and Foreign Policy in Turkey: New Elections, Troubling Trends (Policy Focus 67, The Washington Institute for Near East Policy, April 2007), http://www.washingtoninstitute.org/ templateC04.php?CID $=268$.

23. The text of the shared vision, 'Is the West Losing Turkey?', Economist, Vol.381, No.8500 (21 October 2006), pp.13-14, http://turkey.usembassy.gov/utils/eprintpage.html; 'The Awkward Partners', Economist, Vol.380, No.8497 (30 September 2006), pp.61-2.

24. 'Kurt Sorunu Yabanci Kiskirtmasi' [The Kurdish Problem is Provoked by Outsiders], Milliyet, 24 (2007), available online at http://www.milliyet.com.tr/2007/03/24/guncel/agun.html (accessed 24 March 2007).

25. F. Moustakis and R. Chaudhuri. 'Turkish-Kurdish Relations and the European Union: An Unprecedented Shift in the Kemalist Paradigm?', Mediterranean Quarterly, Vol.16, No.4 (2005), pp.77-89.

26. See http://www.ntvmsnbc.com/news/424073.asp “AB'den Turkiye’ye Dayanisma Mesaji (The support message from EU to Turkey).

27. R. Cakir, Turkiye'nin Kurt Sorunu [Turkey's Kurdish Problem] (Istanbul: Metis Yayinlari, 2004), pp. 13-48.

28. M. Kibaroglu, 'Turkey Says No', The Bulletin of the Atomic Scientists, Vol.59, No.4 (2003), pp.22-5; 'America between the Turks and Kurds', Economist, Vol.381, No.8508 (16 December 2006), pp.43-4; S. Sachs, 'U.S. Tells Turks It Won't Fight Kurds', The New York Times, Vol.154, No.53092 (1 December 2005), p.A10; B. Park, 'Iraq's Kurds and Turkey: Challenges for US Policy', Parameters: US Army War College, Vol.34, No.3 (2004), pp.18-30.

29. M. Kibaroglu, 'Clash of Interest over Northern Iraq Drives Turkish-Israeli Alliance to a Crossroads', The Middle East Journal, Vol.59, No.2 (2005), pp.246-64.

30. D. Phillips, 'A Plan for Iraq’s Kurds', Wall Street Journal, 10 June 2004.

31. George Marshall Fund, http://www.transatlantictrends.org/doc/2006_TT_Key\%20Findings\%20 FINAL.pdf.

32. G. Avci, 'Turkey's Slow EU Candidacy: Insurmountable Hurdles to Membership or Simple Euro-Skepticism', in A. Carkoglu and B. Rubin (eds.), Turkey and the European Union, Domestic Politics, Economic Integration and International Dynamics (London: Frank Cass, 2005), pp.149-70. 
33. P.A. Furia and R.E. Lucas, 'Determinants of Arab Public Opinion on Foreign Relations', International Studies Quarterly, Vol.50, No.3 (2006), pp.585-605.

34. T.K. Evered 'Regionalism in the Middle East and the Case of Turkey', Geographical Review, Vol.95, No.3 (2005), pp.463-77.

35. H.T. Oguzlu, 'Soft Power in Turkish Foreign Policy', Australian Journal of International Affairs, Vol.61, No.1 (2007), pp.81-97.

36. M. Kibaroglu, 'Turkey's Concerns About the State-Building Efforts in Iraq', Iranian Journal of International Affairs, Vol.18, No.4 (2005), pp.443-54.

37. M. Slackman, 'Chaos in Iraq Sends Shockwaves across Middle East and Elevates Iran's Influence', New York Times, Vol.155, No.53503 (27 February 2006), p.A9.

38. 'Iran, United States Quarrel over Gas Deal with Turkey', The Journal of Turkish Weekly, http:// www.turkishweekly.net/news.php?id=46907.

39. A. Kibaroglu and O. Unver, 'An Institutional Framework for Facilitating Cooperation in the Euphrates-Tigris River Basin', International Negotiation: A Journal of Theory and Practice, Vol.5, No.2 (2000), pp.311-30

40. M. Altunisik, 'The Turkish Model and Democratization in the Middle East', Arab Studies Quarterly, Vol.27, No.1-2 (2005), pp.45-63.

41. Z. Onis, 'Turkey's Encounters with the New Europe: Multiple Transformations, Inherent Dilemmas and the Challenges Ahead', Journal of Southern Europe and the Balkans, Vol.8, No.3 (2006), pp.27998.

42. K. Kirisci, Turkey's Foreign Policy in Turbulent Times (Chaillot Paper, Institute for Security Studies, September 2006), http://www.iss-eu.org/chaillot/chai92.pdf.

43. Z. Dagi, 'Orta Doğu perspektifinden Turkiye'nin Avrupa entegrasyonu: Otekilestirme asiliyor mu?', Demokrasi Platformu, Vol.1, No.4 (2005), pp.97-113.

44. The decision of Recep Tayyip Erdogan, Prime Minister as well as the Chairman of the AKP (which has ruled as the single-party government since November 2002), to designate Foreign Minister Abdullah Gul as the only candidate for the next President of the Republic of Turkey attracted severe criticism and strong opposition from the segments of society who were particularly sensitive about the secular characteristic of the regime. To them, Gul was not the person to take over the Presidency, which signified, among other things, Atatürk's secular principles and reforms. The opposition party, the People's Republican Party (Cumhuriyet Halk Partisi-CHP) took the matter to the Constitutional Court on the grounds that the voting was carried out without a two-thirds majority of the members and that the vote should be nullified. Amid this debate, a declaration was published just before midnight on 27 April 2007 on the official website of the Turkish General Staff (www.tsk.mil.tr) addressing directly and indirectly many practices and policy implementations of the AKP government and reminding them of the resolve of the Turkish Armed Forces to act, if need be, as the guardian of Atatürk's secular principles for the effective administration of the state. Many believe that the purpose of the declaration was to affect the vote to be held at the Constitutional Court. The Court's decision, which came only a few days later, was in parallel with the expectations of the opposition party and the General Staff. For a scholarly study on the role of the military in Turkish politics, see I. Toksoz, 'Security Dilemmas and Threat Perceptions: Turkey at the Crossroads' (Unpublished Ph.D. Dissertation, Northeastern University, Boston, MA, 2007). 